\title{
Stå på, ikke gi opp - the use of Norwegian particle verbs in email messages by advanced L2 users whose L1 is Finnish
}

\begin{abstract}
Kristiina Lieri, University of Turku
The aim of the present study is to examine similarities and differences in the use of particle verbs (PVs) between advanced bilingual L2 users of Norwegian (L1 Finnish) in their teens and Norwegian L1 speakers of the same age. The data consists of three writing tasks (email messages) written by 6 bilingual FinnishNorwegian participants and 6 native speakers of Norwegian. Previous research has shown that second language (L2) users, who are highly advanced, face problems using multi-word expressions. For example, they tend to use less $P V s$ than native speakers. The advanced bilingual L2 users of Norwegian (L1 Finnish) in the present study also show a slight tendency to use fewer $P V s$ than the native speakers. However, the Finnish-Norwegian participants used some more idiomatic $P V s$ than the native speakers of Norwegian. The results show that advanced bilingual users of Norwegian who live in an L2 environment and receive a great amount of natural input and output from an early age utilized PVs in a manner congruent to native speakers. Despite differences between the Finnish and Norwegian languages, there are also similarities with regard to PVs. The bilingual participants are familiar with $P V s$ in their first language, Finnish, and they may benefit from that, even though these verbs are not as frequent in Finnish as in Norwegian.
\end{abstract}

Keywords: Norwegian, particle verbs, advanced L2 users of Norwegian

\section{Introduction}

This article discusses the use of Norwegian particle verbs (cf. verb-particle combinations, such as give up, write down etc. in English) by advanced language users whose native language is Finnish and who live in Norway in a multicultural environment. The use of particle verbs by L2 speakers is compared to that of a group of native Norwegian speakers of the same age.

In Norwegian, like in other Germanic languages, there are a large number of multi-word verbs, particle verbs (PVs), e.g. legge ned 'to lay down' / to shut down'. Such verbs consist of a verb and one or more following verbal particles (Faarlund, Lie, \& Vannebo, 1997). In addition to verbs compounded with separable particles (å legge ned), there are also inseparable forms (å nedlegge), but

Corresponding author's email: kristiina.s.lieri@utu.fi eISSN: 1457-9863

Publisher: University of Jyväskylä, Language Campus (C) 2020: The authors https://apples.journal.fi https://doi.org/10.47862/apples.99136 
they will be excluded from this study (see Faarlund et al., 1997, p. 80-83). Previous research has demonstrated that semantically complex verb-particle combinations present a challenge not only for second language (L2) learners (Hulstijn \& Marchena, 1989; Liao \& Fukuya, 2004; Siyanova \& Schmitt, 2007) but also for language teachers in how to classify and teach them (Celce-Murcia \& Larsen-Freeman, 1999). Native speakers frequently utilize PVs in spoken language and they are also constantly used in written language, especially informally (Siyanova \& Schmitt, 2007). Thus, learners' knowledge of these multi-word units is crucial to acquire nativelike proficiency, i.e., how to express certain contents in a natural or nativelike manner in the language in question (nativelike selection, see Pawley \& Syder, 1983, p.193). However, it is the idiomatic use of PVs that often distinguishes L2 users, even those at an advanced level, from native speakers (Gustafsson, Verspoor, \& Lowie, 2012; Wray, 2002).

While the use of English PVs among L2 users has been widely studied (see e.g. Blais \& Gonnermann, 2013; Hulstijn \& Marchena, 1989; Kharitonova, 2013; Liao \& Fukuya, 2004; Sjöholm, 1995; Yildiz, 2016), there is less research available on Scandinavian languages (Ekberg, 1999; Enström, 1996; Golden, 2005; Ylikiiskilä, 2001). Therefore, the present study aims to fill the gap. The main goal is to find out similarities and differences in the use of PVs in email messages written by advanced bilingual L2 users of Norwegian (L1 Finnish) in their teens and Norwegian L1 speakers of the same age. The specific research questions are the following:

Research Question 1: What kind of Norwegian PVs do advanced L2 users of Norwegian (L1 Finnish) and Norwegian L1 speakers use in emails?

Research Question 2: What do the findings show about the similarities and differences in the use of PVs between these two groups?

Due to the small number of participants, the focus of the present study lies on qualitative aspects. The end of the article discusses how the findings could be applied to L2 language teaching.

This article is structured as follows: First, I will focus on theoretical considerations, definitions, and previous research. Secondly, I will introduce the material and methodology used in the current study. Then, I will present and discuss the findings of this study and how the material might be relevant to language teaching. In the conclusion I will sum up the main findings and give suggestions for further studies.

\section{Theoretical considerations and previous studies}

In this chapter, theoretical issues and definitions as well as the mastery of PVs in previous studies are discussed.

\subsection{Usage-based model of language}

This study relies on the dynamic usage-based view of language (UBL). In brief, language is a large selection of linguistic units seen as conventionalized formmeaning pairings with different levels of specificity and schematicity (Goldberg, 2006; Langacker, 2000). Linguistic units are seen as compositions of grammatical, semantic and pragmatic patterns in which lexicon and grammar are considered to form a continuum from simple to complex, and from lexically open to lexically 
specified (Bybee, 2006, p. 715; Croft \& Cruse, 2004, p. 240, 255; Langacker, 1987, p. 25-27; Wray, 2002, p. 62-65). These units are linked to each other through family resemblance, and they make up a network (Bybee, 2006, p.730).

UBL emphasizes that language users' knowledge of language emerges from experiences with the language (Bybee, 2006; Goldberg, 2006; Langacker, 1987; Tomasello, 2003). Language itself is seen as a dynamic system consisting of many different sub-systems (e.g. the morpheme and lexical system) that are in continuous change (Larsen-Freeman, 1997). Language learning is a non-linear process, and develops as a result of frequent and meaningful exposure to and use of a language (Bybee, 2006, p. 730). According to UBL, language is an exemplar-based system whose mastery is primarily frequency-driven (Tomasello, 2003). In this study, frequency in the input and output are seen as the main factors driving language development. Language users are assumed to note the regularities and patterns of a language through exposure and experiences with the language (Ellis, 2002).

\subsection{Particle verbs}

In research literature, the use of terminology related to multi-word verbs is inconsistent and a source of confusion (Alejo González, 2010; Liu, 2011). In English, for example, phrasal verbs, compound verbs, and verb-particle constructions are used for such verbs. In this article, the term particle verb is used since it is a frequent term in Norwegian research literature (Golden, 2005; Golden, MacDonald, \& Ryen, 2014; Haugen, 2009).

PVs can be integrated into phraseological or polylexical expressions (Alejo González, 2010; Kolehmainen, 2006). Such verbs consist of more than one lexeme, and the attached verbal particle is an integral part of the verb (e.g. komme an pa 'to depend on'). Together these form a conventionalized ${ }^{1}$ lexical unit which has not only a conventionalized form but also its own semantics (Celce-Murcia \& Larsen-Freeman, 1999, p. 265; Enström, 2013, p. 190; see also Dehé, 2015). By conventionalization I mean frequent and repeated use of certain lexical units for particular purposes in a speech community (Kecskes, 2015, p. 31; see also Gustafsson et al., 2012, p. 3). In all languages, a small number of verbs appear to be dominant in terms of frequency (Viberg, 2004). Such nuclear verbs, e.g. $g a ̊$ 'to go', komme 'to come', ta 'to take' make up the majority of PVs with different particles (Sjöholm, 1995, p. 106; for English Liu, 2011, p. 662; Wray, 2002, p. 2930). Verbal particles are homonymous with adverbs ( $u t^{\prime}$ 'out', opp 'up') or prepositions (over 'over', under' under') but do not have their own complements'2, i.e., Han drakk opp vinen 'he drank up the wine' the nominal 'wine' is a complement to the verb (Faarlund et al., 1997, p. 699; see also Golden et al., 2014, p. 24).

Many PVs are polysemous, i.e., they have multiple meanings which emerge in specific contexts (Golden, 2005, p.115; Liu \& Myers, 2018, p. 3-4; Siyanova \& Schmitt, 2007, p. 120; Sjöholm, 1995, p. 103; Strzelecka, 2003, p. 267; Taylor, 2002, p. 439). For example, the verb ta opp 'to take up' has different meanings. Ta opp saker means 'to bring up items', ta opp video 'to record' and ta opp eksamen 'to take a test/an exam'. One likely reason that PVs are difficult for L2 users is the many possibilities for interpretation when two (or more) polysemous and frequent words are combined (Enström, 2013, p. 184; Golden, 2017, p. 11-12).

Norwegian PVs have some semantic, syntactic and phonological features that distinguish them from a single verb + preposition combination, such as Jeg prøvde $\stackrel{a}{\circ}$ 
komme på toget 'I tried to get on the train' (see e.g. Faarlund et al., 1997; Golden et al., 2014; Haugen, 2009). These properties will be outlined below. However, in the present study, I will be concerned primarily with the semantic properties of PVs.

The meaning of a PV often results from the meanings of its parts and the manner in which they are combined (Taylor, 2002, p. 97). However, PVs can be placed on a continuum from semantically transparent (compositional) PVs, e.g. Hun gar ut gjennom porten 'she walks out through the gate' to PVs with an idiomatic (non-compositional) meaning Hun vokste opp i Paris 'she grew up in Paris' (see Table 1). The meaning of transparent (literal) ${ }^{3}$ PVs is determined by the literal interpretations of the verb and the verbal particle. The lexical meaning of PVs remains close to the basic or prototypical meanings of the individual words (Strzelecka, 2003). Mostly, these verbs denote movement and the verbal particles are used in directional or spatial meaning (Faarlund et al., 1997, p. 465467; Larsen, 2014, p. 4; see also Berntsen, 2009, p. 22-30).

Table 1. Norwegian particle verb continuum.

Transparent (compositional) PVs Idiomatic (non-compositional) PVs

gå ut 'to go out' / reise bort 'to travel away' vokse opp 'to grow up'/ stå på 'to persist'

Idiomatic (figurative) PVs are highly conventionalized and often also lexicalized, i.e., stored as a single unit in the mental lexicon (Dehé, 2002). The holistic meaning of these PVs is not fully predictable from the prototypical meanings of the individual constituents (Strzelecka, 2003, p. 20). In idiomatic PVs, the verbal particle has lost its original (spatial) meaning and as a result, the verb gets a more abstract meaning (Enström, 1996, p. 106, 140). As opposed to transparent PVs, idiomatic ones tend to be demanding for L2 users as they require a figurative interpretation (Hovland, 1997; Laufer \& Eliasson, 1993; Yildiz, 2016). In addition, many PVs are ambiguous as they can be interpreted literally or figuratively depending on the context, e.g. gå inn 'to go inside' or gå inn i saken 'to engage in' (Golden, 2005, p. 72; Paulmann, Ghareeb-Ali \& Felser, 2015, p. 245-246).

Some verbal particles as opp 'up' and $u t$ 'out' together with verbs denote Aktionsart, i.e., describe internal time structures of situations (Vendler, 1957)4 . A simple verb (example 1a) is usually neutral with regard to Aktionsart, whereas in example $1 b$, the action described by the verb is completed and is said to be bounded or telic (Faarlund et al., 1997, p. 642; Strzelecka, 2003, p. 19; Zielonka, 2004, p. 173; see also Dehé, 2002). In contrast, the preposition på 'on' (example 1c) is used to indicate that the action is continuing (unbounded, atelic), lacking the implication of an endpoint ${ }^{5}$. When the verbal particle marks completeness or continuation, they lose their literal, directional meaning (Dehé, 2002).

1 a. Tom spiser et eple.

Tom eats an apple

'Tom eats an apple'

b. Tom spiser opp et eple.

Tom eats up an apple

'Tom eats up an apple, eats up entirely'

c. Tom spiser på et eple ${ }^{6}$.

Tom eats on an apple

'Tom is eating an apple' 
Norwegian compound PVs (e.g. dra opp 'to pull up') have often, but not always an inseparable counterpart (oppdra 'to raise'). They can have the same meaning (e.g. ta opp/oppta studenter 'to enroll students'), slightly different meaning (e.g. sette fram et forslag 'to put forward a proposal' / framsette et forslag 'to make a proposal') or completely different meaning as dra opp and oppdra. The tendency is that inseparable verbs have an abstract meaning and compound verbs have a concrete meaning. Furthermore, there is a tendency that PVs (e.g. ̊̊ selge ut 'to sell out') form participles, especially perfect participles, e.g. Produktet er utsolgt meaning 'the product is sold out' (Faarlund et al., 1997; 83-87; Golden et al., 2014, p. 124).

The syntactic behaviour of Norwegian PVs has frequently been described in the literature (Haugen, 2009; Larsson \& Lundquist, 2014). In Norwegian, PVs differ from a simple verb + preposition combination [V+Pre+NP] syntactically (Golden et al., 2014, p.124; Faarlund et al., 1997, p. 697-702). While a preposition always precedes its NP (Katten hoppet på stolen/*Katten hoppet stolen $p a ̊$ 'The cat jumped onto the chair'), verbal particles may precede (Lisa kastet ut katten' Lisa threw out the cat') or follow a NP (Lisa kastet katten ut 'Lisa threw the cat out') with regard to transparent PVs. In addition to verb particle alternation, there are also some other syntactic differences (e.g. topicalization and clefting) between transparent and idiomatic PVs (see Aa, 2015; Faarlund et al., 1997; Haugen, 2009; Larsson \& Lundquist, 2014). However, the present study is not focused on verbal particles and particle shift, so it will not be discussed in detail.

Intonation is one feature that distinguishes Norwegian PVs from a verb + preposition combination. The verb and the verbal particle form a prosodic unit that is dialect-bounded. In Eastern Norwegian (includes the Oslo dialect that can be considered as standard Bokmål, i.e., one of the two official forms of written Norwegian), the main stress is typically on the verb and the secondary stress on the particle, while in some dialects the particle carries the main stress and the verb itself is unstressed (Aa, 2015, p. 84-85; Faarlund et al., 1997, p. 700; Larsson \& Lundquist, 2014, p. 102). Since the stress is not visible in written language, only semantic/syntactic clues show whether a PV or verb + preposition combination is involved in the material analyzed.

\subsection{Particle verbs in previous L2 studies}

Previous research has shown that there are similarities and differences in the use of PVs between native speakers and non-native speakers, but the results from the literature are contradictory and inconclusive. One central question has been whether structural differences between the native language and target language have any effect on the use of PVs in L2. Several studies have demonstrated that L2 users tend to avoid PVs if they do not exist in their first language (Blais \& Gonnermann, 2013; Hulstijn \& Marchena, 1989; Siyanova \& Schmitt, 2007; Sjöholm, 1995). L2 users tend to use one-word verbs (invent) with prototypical meanings that they fully comprehend, instead of PVs (make up) with a more abstract meaning (Siyanova \& Schmitt, 2007, p. 120-121; Sjöholm, 1995, p. 107). One reason for this may be that they lack strategies to deal with them. Furthermore, semantic models that are established in L1 are difficult to reorganize (Holum, 2010, p. 29; see also, Gujord, 2013).

On the other hand, the research findings of Mondor (2008) and Kharitonova (2013) revealed that Swedish and Norwegian speakers of English had a strong preference to use PVs that appear similar to Swedish/Norwegian ones. They 
also found evidence of negative transfer from L1 into English. Mondor's (2008) results showed that advanced Swedish learners of English overused PVs in argumentative writing with a cross-linguistic link to Swedish, e.g. *I tried to melt in (Swedish 'smälta in') instead of blend in. Similarly, Kharitonova (2013) demonstrated that Norwegian participants used Norwegian-like PVs with the wrong meaning in English. However, her findings did not show that Norwegian speakers would avoid PVs less often than Russian speakers of English whose L1 does not have PVs.

Another controversial matter is language users' proficiency level. L2 learners, specifically at the beginner level, are less likely to use PVs than native speakers, and they tend to prefer one-word verbs to multi-word ones (Sjöholm, 1995). Siyanova and Schmitt (2007) also found that advanced users of English showed a higher tendency to use one-word verbs compared to native speakers. Hulstijn and Marchena (1989) examined intermediate and advanced Dutch learners of English (multiple-choice, memorization and translation test). They concluded that neither intermediate nor advanced learners avoided phrasal verbs as a category, but they showed a tendency to avoid PVs that were similar to their L1 equivalents to prevent L1-based errors.

Laufer and Eliasson (1993) studied advanced Swedish- and Hebrew-speaking learners of English and found out that the Swedish participants used significantly more PVs, especially idiomatic ones, than the native Hebrews. Many English PVs have an equivalent in Swedish while PVs do not exist in Hebrew, and notably idiomatic PVs were challenging. Also Hovland's (1997) findings in written production indicated that idiomatic PV constructions in Norwegian were more difficult for L2 learners. A more recent study of Yildiz (2016) showed that besides a lacking L1 counterpart and lower language proficiency, the semantic complexity of PVs was an important factor. Turkish university students at an intermediate level avoided English PVs in multiplechoice tests as a whole, but as their English proficiency increased, the avoidance of transparent PVs diminished. Contrary to Turkish learners, Norwegian university students did not significantly differ from native speakers with regard to their use of PVs.

The findings of Swedish and Norwegian studies have demonstrated that the idiomatic use of PVs distinguishes bilingual L2 speakers from native speakers. Enström (1996) examined advanced bilingual learners of Swedish and native speakers of Swedish $(\mathrm{n}=44)$ at upper secondary school and found significant differences between the two groups. Compared to L2 essays (elicited task), the use of PVs was twice as high in L1 essays. L1 students also had more than twice as many different PVs. L2 users tended to overuse certain verbs and underuse others. They also had more incorrect use of particles with idiomatic PVs. Ekberg (1999) studied complex predicates (PVs and reflexive verbs) in oral production. To some degree, her results differed from Enström's (1996) findings. Bilingual participants (some years younger than those in Enström's study) used fewer PVs, idiomatic ones in particular, but did not differ from native speakers in regard to misusing, overusing or underusing verbal particles. Another interesting finding in Ekberg's (1999) study was how the most frequent PVs were distributed between the two groups. The results showed that native speakers seemed to have a larger set of prefabricated expressions (see Wray, 2002), i.e., PVs that were stored and retrieved as a whole from memory at the time of use, in comparison to L2 learners. The five most used PVs in oral tasks were more 
common among native speakers than bilingual users, who had more PVs which occurred just once. Native speakers' use of PVs was more stereotyped while bilingual relied more on creative language choices and their language was less idiomatic.

Golden (2005) explored the understanding of metaphorical words and expressions, including some PVs, in Norwegian social studies books (a multichoice task) among 15-year-old native L1 speakers $(\mathrm{n}=230)$ and L2 users (n $=170$ ). She found that native speakers had a better understanding of PVs than L2 users. In addition to language proficiency and semantic transparency of PVs, language use at home, day care, and the age of the learners at the start of school affected the results. Ylikiiskilä (2001) studied the use of Swedish verbs in some oral tasks among 20 Swedish-Finnish children who were 10-13 years old and bilingual from birth, and compared the results with a group of monolingual Swedish children of the same age and similar socioeconomic background. His findings revealed that there were no significant differences regarding the proportion of PVs or the number of PVs that occurred just once between the bilingual and native speakers' groups. However, individual differences with regard to PVs which occurred just once were great within the bilingual group.

\section{The study}

In the following, the participants as well as the material and the method of analysis are presented.

\subsection{Participants}

Six Finnish-Norwegian participants (two boys and four girls) aged 12-19 took part in the study. All of them had learnt Finnish as their L1. Both parents of the participants were Finnish speakers and moved to work in Norway as adults. One participant was born in Finland and moved to Norway when she was one year old, while the others were born and raised in Norway (see Table 2). All of the participants started in Norwegian day care before they turned three years old and went to a Norwegian school at the age of six. Their general language skills in Norwegian were not tested, but their proficiency can be considered as advanced both in Norwegian and Finnish. Their use of Finnish is mainly limited to home and to contacts with family and friends living in Finland ${ }^{7}$. The families live in the Greater Oslo area in neighborhoods where the majority of residents are native Norwegian. Most schoolmates and friends are also Norwegian. In addition, there are few other Finnish-speaking teens in the Oslo area. Therefore, the Finnish-Norwegian participants are mostly exposed to Norwegian in their daily life. The data of the advanced L2 users is compared to six Norwegian L1 speakers of the same age (12-19) and with a similar socioeconomic background (two boys and four girls). All the participants can be considered as bi/multilingual as they speak at least English in addition to Norwegian and Finnish (Finnish-Norwegian participants).

Based on previous research (Ekberg, 1999; Enström, 1996; Golden, 2005), it is assumed that the performance of the Finnish-Norwegian participants might differ from that of the native speakers of Norwegian due to differences in the amount of input and output in an L2 setting. Despite extensive exposure to 
Norwegian from an early age, the teens with two languages are likely to be less exposed to each language than a native speaker to their language (Treffers-Daller 2018, p. 294). They use their languages for different purposes in everyday life. For example, they use one language at home and another at school and in free time.

\subsection{Material and Method}

The data consists of three writing tasks (email messages) that were collected in 2017-2018. The participants were asked to write around 200 words on each topic (daily life, holidays and plans for the next term). The advantage of the test type (elicited) is that it provides information on the participants' active language skills. If they are confident in the use of PVs, they will not avoid them (see e.g. Chaudron, 2003).

The Finnish-Norwegian participants wrote 4,249 lexemes and the native speakers of Norwegian 4,025 lexemes. The length of the emails varied from 500 to 1,000 lexemes. First, I excerpted all the occurrences of PVs in emails manually and then I categorized them into transparent and idiomatic PVs. After the categorization I calculated the PVs, the percentages of the above categories, and PV frequency per 100 words for each participant. Qualitative approaches were used to examine the idiomatic use of PVs. In written material, it can sometimes be difficult to distinguish between PVs and other types of verb + preposition combinations (Haugen, 2009; Strzelecka, 2003; Sundman, 2010). Therefore, two adult native speakers of Norwegian were asked to read the emails and judge whether the verb-particle combinations were PVs or not in the context (cf. Gustafsson et al., 2012). While reviewing the data I have relied on scientific descriptions of the Norwegian language, especially Norsk referansegrammatikk by Faarlund et al. (1997). In addition, I have consulted the dictionaries Bokmålsordboka and Det Norske Akademis ordbok when determining the meanings of PVs. I carried out a frequency check for each PV in Leksikografisk bokmålskorpus ${ }^{8}$ (simple corpus search 25.2.2019).

\section{Findings and interpretations}

My aim is to look more closely at the similarities and differences in the use of PVs in the emails written by advanced bilingual L2 users of Norwegian (L1 Finnish) and Norwegian L1 speakers. Due to the small amount of material, no inferential statistics are included and the focus is on qualitative analysis. First, however, I am going to give an overview of the use of PVs among FinnishNorwegian speakers and native Norwegian speakers.

\subsection{Particle verbs in the emails}

In total, the participants produced $88 \mathrm{PVs}$ in the emails: Finnish-Norwegian participants (FN group) $42 \mathrm{PVs}$ and native Norwegian speakers (NO group) 46 PVs (a full list of the PVs used can be found in Table 1 in the Appendix). The results show that the proportion of PVs was similar but the native speakers of Norwegian produced slightly more PVs (1,14/100 words) compared to the Finnish-Norwegian group (0,99/100 words) and they also had more different PVs (30 verbs) than Finnish-Norwegian speakers (24 verbs). Interestingly, the 
Finnish-Norwegian speakers produced somewhat more idiomatic PVs (22 out of 42 , that is $52 \%$ of all the PVs) than the native speakers' group (17 out of 46 , that is $37 \%$ ). This finding differs from previous results (see e.g. Ekberg, 1999; Enström, 1996; Sjöholm, 1995) which have shown that L2 users tend to use fewer idiomatic PVs in written and spoken language than native speakers. The Finnish-Norwegian speakers had slightly less PVs that occurred just once (43\% of all PVs) compared to the Norwegian speakers (48\%).This finding is in line with Ylikiiskilä's (2001) results where bilingual Swedish-Finnish participants produced fewer PVs that occurred just once than native speakers of Swedish (cf. Ekberg, 1999; Enström, 1996). The findings of the present study demonstrate that the native speaker's use of PVs was less stereotyped than the bilingual FinnishNorwegian speakers' (cf. Ekberg, 1999). Due to the small sample, however, it is not possible to draw far-reaching conclusions from the findings.

The most frequently used PVs in written tasks among Finnish-Norwegian speakers were vokse opp 'to grow up' (7), komme inn 'to come in' (5), komme hjem 'to come home' (4) and gå ut 'to go out' (4). In comparison, the most frequent verbs used by the Norwegian speakers were komme hjem 'to come home' (6), stå opp 'to get up' (4), komme inn 'to come in' (3) and kjøre opp 'to take a driving test' (3). The four most frequent PVs accounted for $48 \%$ of the total number of PV occurrences in the Finnish-Norwegian speakers' group and $35 \%$ in the Norwegian speakers' group (see Appendix).

As mentioned earlier, nuclear verbs account for the majority of PVs in many languages (Sjöholm, 1995, p.106; Viberg, 2004; for English Wray, 2002, p. 29-30). In this study, the most frequently used Norwegian verbs among FinnishNorwegian speakers were komme 'to come' (10), vokse 'to grow' (7) and ga 'to go' (6) while native Norwegian speakers preferred komme 'to come' (10), kjøre 'to drive'(6) and stå 'to stand' (5). By far the four most common verbal particles were opp 'up', ut 'out', inn 'in' and hjem 'home'. They accounted for well over $70 \%$ of all the particles in both groups (see Appendix). Verbal particles may add a directional, locative, resultative or aspectual component to the meaning of a complex verb, or the verb-particle combination may have an idiomatic meaning (Dehé, 2015; Strzelecka, 2003). The verbal particle opp 'up' (15 hits) was overwhelmingly most frequently used in verb-particle combinations before $u t$ 'out' (8 hits) among Finnish-Norwegian speakers while the same verbal particles had as many hits (10) among Norwegian speakers. Both verbal particles are highly polysemous and do not only express directional motion but are also used with other implications (cf. Alejo González, 2010, p. 63). The particle inn 'in' appeared mainly in the PV combination komme inn (på skole) 'to get into a school' and hjem 'home' only with the verb komme 'to come'.

The participants wrote about their daily life, holidays and plans for the next term. The content of the emails may have influenced the choice of PVs. A great number of PVs in the emails, e.g. ga ut 'to go out', stå opp 'to get up' and reise bort 'to travel away' denote movement and action and they are common when telling about daily activities and holiday plans. The verb vokse opp 'to grow up' was the most frequent PV among the Finnish-Norwegian speakers, but it did not occur at all among the native speakers. The Finnish-Norwegian teens often used the verb when describing the similarities and differences between Norway and Finland. The most frequently used PVs in the emails are also frequent in Leksikografisk bokmålskorpus: komme inn 'to come in' (2853 hits), komme hjem 'to come home' (1085 hits), stå opp 'to get up' (1020 hits) and vokse opp 'to grow up' 
(637 hits). This is consistent with theoretical assumptions based on UBL that frequency is a major factor determining what language users notice in the language they hear and read, learn, and represent in the mental lexicon (Gustafsson et al., 2012; Siyanova-Chanturia \& van Lancker Sidtis, 2019, p. 55).

The results show that the individual differences within the two groups were large with regard to the proportions of PVs (cf. Ylikiiskilä, 2001). The FinnishNorwegian speakers produced between 4 and 11 PVs (median 6.5) and the native Norwegian speakers between 4 and 13 (median 7). The individual variation is presented in Table 2 . When it comes to the individual variation, it is more prominent among native speakers while Finnish-Norwegian speakers are more homogenous. This is a result that differs from Enström's study (1996) where the individual variations were more notable among the L2 speakers.

The findings reveal that the three participants that produced most PVs per 100 words belong to the native speakers' group. The participant who produced the largest number of PVs (13 PVs in total) had many transparent PVs. This might have been due to the fact that she wrote about taking a driving test and she used a lot of verbs expressing action and movement. Three participants produced fewer PVs than the others. Two of them were native speakers and one was a Finnish-Norwegian speaker. There is no obvious explanation for this and the length of the emails does not directly seem to affect the number of PVs.

Table 2. Individual differences between advanced L2 users of Norwegian (L1 Finnish) and Norwegian L1 speaker.

\begin{tabular}{lcccccc}
\hline & Age & $\begin{array}{c}\text { Proportions } \\
\text { of PVs }\end{array}$ & $\begin{array}{c}\text { PV frequency } \\
\text { per 100 words }\end{array}$ & $\begin{array}{c}\text { Number of } \\
\text { words }\end{array}$ & $\begin{array}{c}\text { Transparent } \\
\text { PVs }\end{array}$ & $\begin{array}{c}\text { Idiomatic } \\
\text { PVs }\end{array}$ \\
\hline FN 1 girl & 16 & 11 & 1,05 & 1044 & 4 & 7 \\
\hline FN 2 girl & 19 & 7 & 1,13 & 622 & 2 & 5 \\
\hline FN 3 boy & 12 & 4 & 0,78 & 515 & 2 & 2 \\
\hline FN 4 girl & 13 & 9 & 0,95 & 944 & 7 & 2 \\
\hline FN 5 boy & 15 & 5 & 0,92 & 542 & 3 & 2 \\
\hline FN 6 girl & 16 & 6 & 1,03 & 582 & 2 & 4 \\
\hline NO 1 girl & 19 & 13 & 1,67 & 777 & 8 & 5 \\
\hline NO 2 girl & 15 & 9 & 1,20 & 749 & 4 & 5 \\
\hline NO 3 boy & 15 & 5 & 1,03 & 482 & 4 & 1 \\
\hline NO 4 boy & 13 & 4 & 0,85 & 472 & 4 & 0 \\
\hline NO 5 girl & 12 & 11 & 1,33 & 824 & 7 & 4 \\
\hline NO 6 girl & 16 & 4 & 0,55 & 721 & 3 & 1 \\
\hline
\end{tabular}

FN = advanced L2 user of Norwegian (L1 Finnish), NO = Norwegian L1 speaker

As seen, the proportion of semantically transparent PVs among FinnishNorwegian and native Norwegian speakers is high (FN group $48 \%$ and NO group $63 \%$ ). As previous studies have shown, these kinds of PVs tend to pose less difficulty for language users because of the universality and the transparency of the combined meanings of the verb and the particle (Sjöholm, 1995; Yildiz, 2016). Even though Finnish and Norwegian languages are structurally different and belong to different language families, there are also similarities. Both languages belong to so-called satellite-framed languages where the information about direction is expressed by verbal particles outside the verb, 
komme inn 'astua sisään' / 'to come in', in contrast to verb-framed languages 9 (e.g. Romance languages) where the information is included in the main verb (e.g. entrer 'to come in' in French) (Talmy, 2000; for Finnish see Lehismets, 2014). Language users whose L1 and L2 share the same lexicalization patterns for motion events will benefit from positive cross-linguistic influence. A large majority of transparent PVs expressing the direction of movement have a structural and semantic frame close to those of Finnish.

The participants in the present study were asked to write about their daily life, holidays and plans for the next term. Thus, describing human actions (komme hjem 'to come home', gå ut 'to go out', stå opp 'to get up') constitutes a large part of PVs in emails (cf. Liu, 2011; Liu \& Myers, 2018). The emails also included some examples where PVs denote Aktionsart. The PVs including lative particles, typically inn 'in', opp 'up' and $u t^{\prime}$ 'out' (examples 2-3), are resultative, in other words, the action has a clear endpoint (Berntsen, 2009, p. 51-55; Strzelecka, 2003, p. 90-91), while the verbal particle rundt 'around' (example 4) indicates ongoing Aktionsart (Celce-Murcia \& Larsen-Freeman, 1999, p. 432-433; Faarlund et al., 1997, p. 703; see also Walková, 2015).

2 Jeg har vært veldig heldig med hvilken skole jeg kom inn på. (FN 1) I have been very lucky with which school I came in on 'I have been very lucky with which school I entered'

3 En hyggelig ungdom hjalp oss med å ta han (hunden) opp av vannet. (FN 4) a nice youth helped us with to take him (the dog) up off the water 'A nice youth helped us get him (the dog) out of the water'

4 Vi reiser rundt i Norge. (FN 4) we travel around in Norge 'We travel around Norway'

The findings of the current study demonstrate that the advanced bilingual Finnish-Norwegian speakers did not avoid idiomatic (figurative) PVs. Even though PVs are not as common in Finnish as in Norwegian and the most idiomatic ones are completely lacking, there are still PVs that have some kind of counterparts in the participants' L1, which bilingual participants may benefit from (Iso suomen kielioppi, VISK $2004 \S 430,455$; see also Kolehmainen, Meriläinen \& Riionheimo, 2014). The idiomatic PVs in examples 5-7 have equivalent expressions in Finnish, e.g. å gi opp 'antaa periksi' / 'to give up', å få til 'saada aikaan'; 'to be/get done; to achieve' and a kaste opp 'antaa ylen' / oksentaa'; 'to throw up'/'to vomit'. In example 8, there is no Finnish multi-word verb but it is possible to visualize the situation by evoking a mental image or use extra-linguistic knowledge (Golden, 2005, p. 126-131).

5 Jeg skal ikke gi opp, jeg skal stå på. (FN 5)

I shall not give up, I shall stand on

'I'm not going to give up, I'll persist'

6 Vi tre hadde vært venner siden barneskolen og ville få til en liten tur sammen før vi skulle flytte hvert til vårt og skilles. (FN 2)

we three had been friends since the-children-school and wanted get to a little trip together before we would move each to ours and separate

'We three had been friends since elementary school and wanted to organize a little trip together before we were to move' 
7 Dagen etter begynte alle å kaste opp. (NO 3) the day after began all to throw up

'The next day, everyone started to throw up'

8 I desember baker vi pepperkaker, pynter huset og lager klart deler av julemiddagen som kan fryses ned i mellomtiden. (FN 2)

in December bake we pepper-cakes, decorate the house and make clear parts off the Christmas-dinner that can freeze.PASS down in the-between-time

'In December we bake gingerbread, decorate the house and prepare some parts of the Christmas dinner that can be frozen in the meantime'

Research carried out within the framework of cognitive linguistics assumes a certain degree of compositionality for all PVs, even for those with an idiomatic (figurative) meaning (Boers \& Lindstroemberg, 2008, p. 21; Taylor, 2002, p. 555). The meanings of particles are often metaphorical extensions of one of the literal senses of the particles and can be traced back to their directional meanings (Alejo González, 2010, p. 58; Golden, 2005, p. 126-128; Kecskes, 2015, p. 38; Larsen, 2014, p.5; Pellicer-Sánchez \& Boers, 2019, p. 165; Strzelecka, 2003, p. 1719). In example 9 se opp til 'to look up to/to admire' it is not difficult to conclude that admiration is in question. In example 10, however, it is more difficult to work out the meaning of the PV because it is used metaphorically.

9 Dette var nok en såpass spesiell opplevelse for meg fordi jeg ser veldig opp til dyktige musikere (FN 1).

this was ADV an enough special experience for me because I see very up to talented musicians 'This was probably such a special experience for me because I very much look up to / admire talented musicians

10 Da vi fant flybilletter til kun $139 \mathrm{kr}$ slo vi til. (FN 2)

when we found flight tickets to only 139 crowns hit we to

'When we found flight tickets for only 139 crowns, we did not hesitate to buy them right away'

Used in conjunction with verbs, verbal particles can have a number of different, often disparate, meanings (Larsen, 2014, p. 39; Strzelecka, 2003, p. 115-116). In the present study, the particle opp 'up' was a frequently used verbal particle in the PVs in both groups (examples 11-13). In Scandinavian languages, the verbal particle opp 'up' occurs often with highly frequent verbs in different contexts (Eeg, 2017; Strzelecka, 2003; Zivanovic, 2016). A large number of verb + opp combinations are idiomatic PVs, such as ende opp 'to end up' and vokse opp 'to grow up' (example 11). The particle opp 'up' also occurs several times in the meaning 'to take a test' (examples 12-13).

11 Jeg tror at hvis jeg hadde vokst opp i Finland ville livet mitt vært annerledes på mange måter. (FN 1)

I think that if I had grown up in Finland would the-life my/POSS been different on many ways 'I think if I had grown up in Finland, my life would have been different in many ways'

12 Jeg har teknisk sett ikke språkfag fordi jeg går opp som privatist i finsk. (FN 1) I have technical way not language-subject because I go up as external-candidate in Finnish 'Technically, I do not have language classes because I study Finnish privately'

13 Alle jeg kjenner som har kjørt opp med han hadde bestått. (NO 1) all I know who have driven up with him had passed

'All of the people I know who have had driving lessons with him had passed their driving test' 
Previous studies (Enström, 1996; Mondor, 2008) have shown that L2 users differ from native speakers by underusing or overusing particles but in this data both were rare. However, in example 14, the Finnish-Norwegian participant emphasizes the particle opp 'up' in an inappropriate context when writing about Finnish Independence Day celebration. There was also one example where both a Finnish-Norwegian and a native Norwegian speaker overused another frequent verbal particle $u t$ 'out'. The multi-word expression det føles $u t$ 'it feels like' (example 15) was used instead of the conventionalized expression det føles. The expressions det ser ut 'it looks' and det høres ut 'it sounds' may have functioned as a pattern for the expression.

14 Vi pleier å sette opp to blå-hvite lys på ett bord i stua. (FN 1) we tend to put up two blue-white candles on a table in the living room 'We usually put two blue-white candles on the table in the living room'

15 Derfor føltes det ut som at jeg ikke kunne være $100 \%$ meg selv. (FN 1) therefore felt it out that I not could be $100 \%$ me self 'That's why it felt like I couldn't be $100 \%$ myself'

\subsection{Pedagogical implications of the results}

Even though the results of the current study do not show significant differences in the use of PVs between advanced bilingual L2 users of Norwegian (L1 Finnish) and native Norwegian speakers, previous research has shown that such verbs are difficult for L2 users because they are often polysemous, non-compositional, and have no equivalent in most languages. It is important for both L1 and L2 users to have a large and varied vocabulary to be able to understand what is being said and written in different contexts and be able to express themselves precisely (Enström, 2013). As PVs are used widely in everyday language, comprehending and producing them is vital to all L2 users, but especially for those who want to reach nativelike fluency. This is why more attention should be paid to the teaching of PVs from an early stage of language learning (PellicerSánchez \& Boers, 2019, p. 153).

It is suggested that teachers should raise students' lexical awareness of PVs and their underlying semantic systems (Armstrong, 2004; White, 2012). White (2012, p. 429) argues that learners should learn to break through the opacity and idiomaticity of PVs and view the verbs as constructions that are conceptually motivated rather than as seemingly arbitrary combinations of verb-particle combinations. Teaching students the basic meaning of verbal particles and then their extensions, i.e., how these can be used in different contexts, may be especially beneficial and will help them to better understand figurative meanings of these multi-word units (Alejo González, 2010; Celce-Murcia \& Larsen-Freeman, 1999, p. 401; Thornbury, 2002; see also Boers \& Lindstroemberg, 2008). Once one gets to know the extended meaning of a PV, it is easy to see the link between the figurative meaning of the PV and the image created by its literal meaning, i.e., spise opp maten meaning 'to eat up food entirely' and lese ut teksten 'to read aloud the text.'

In class, teachers should encourage students to use their own imagination/creativity in order to visualize the image of the figurative meaning (White, 2012). For instance, drawings can be used to illustrate the meanings (Boers \& Lindstroemberg, 2008). To give students a more active role in figuring 
out the meaning of PVs is a useful strategy. Students could be given the task of identifying one or more PVs in the authentic material. Then they could discuss which verbs and particles are possible in a particular construction, and how the meaning changes with different particles. For instance, the Norwegian verb $a$ legge 'to put' gets a different meaning with different verbal particles: legge ned 'to lay down' / 'to shut down', legge opp 'to retire', legge inn bud 'to place an offer,' legge $p a$ 'to hang on the phone' and legge på seg 'to put on weight'. Such an approach may also facilitate attempts to make sense of novel PVs that students will meet outside of class (White, 2012) as lot of language learning takes place in informal settings through different media (listening, reading) and interaction with L1 speakers (Pellicer-Sánchez \& Boers, 2019; Schmitt \& Redwood, 2011). Recognizing a PV when meeting one would greatly enhance learners' vocabulary acquisition and also comprehension of everyday Norwegian.

To summarize, teachers should introduce PVs more regularly and systematically to their students from an early stage of language learning. Knowledge of PVs and strategies need to be made concrete through extensive authentic exposure to PVs by reading, listening and various speaking activities (Schmitt \& Redwood, 2011; Thornbury, 2002).

\section{Conclusion}

The aim of the present study was to examine what kinds of Norwegian particle verbs advanced L2 users of Norwegian (L1 Finnish) and Norwegian L1 speakers of the same age use in emails and find out similarities and differences in the use of PVs.

Previous research has demonstrated that non-native speakers use less multiword units, e.g. PVs, than native speakers (Ekberg, 1999; Enström, 1996). On the basis of the present study, there seems to be no evidence that the FinnishNorwegian speakers significantly differ from the native speakers of Norwegian with regard to the use of PVs (cf. Ylikiiskilä, 2001). The results show that the proportions of the PVs in the emails were similar even though native speakers of Norwegian had slightly more different PVs. Thus, the findings of this study do not support the findings of earlier studies (Enström, 1996; Mondor, 2008) that have argued that L2 users differ from native speakers by using fewer PVs. On the other hand, the Finnish-Norwegian participants used idiomatic PVs slightly more than the native speakers, even though these kinds of PVs are not frequent in their L1, Finnish (cf. Ekberg, 1999; Enström, 1996; Yildiz, 2016). Similarly, the Finnish-Norwegian participants used slightly fewer PVs that occurred just once and their use of PVs seemed to be more stereotyped compared to native speakers of Norwegian. Also this finding differs from previous studies (Ekberg, 1999). However, it should be borne in mind that the present study was conducted on a sample too small to allow for generalizations.

All of the findings must be interpreted in light of the fact that the bilingual Finnish-Norwegian participants are advanced speakers of Norwegian. They have lived almost entirely in a Norwegian-speaking environment and they have gone to a Norwegian day care and school. Their L2 (Norwegian) is their primary everyday language and they are much less exposed to their L1 (Finnish) in different daily contexts. They have therefore acquired more or less nativelike proficiency regarding the use of PVs. The findings also imply that there are individual differences within the Finnish-Norwegian speakers and native Norwegian speakers with regard to the number of PVs in the emails. 
To achieve idiomatic language competence, e.g. to know how to use PVs and which verbal particles to combine with certain verbs, long-term, intense and varied contacts with the target language are required. Conventionalized constructions like PVs get automatized by using them in different language situations and contexts as usage-based models of language claim (Goldberg, 2006; Langacker, 2000). For L2 users, frequent and meaningful exposure to and use of language are needed from the beginning. Language development is a dynamic process and it develops throughout a lifetime.

Even though the present study has its limitations, i.e. the small sample of highly advanced bilingual participants and the different topics of the emails might have had an impact on the results, it indicates that advanced bilingual L2 users with extensive exposure to and use of L2 from an early age can perform at native speakers' level.

In order to get further information on how the use of PVs develops, a longitudinal study on the subject should be carried out. There is also need for more research involving L2 users of Norwegian with different L1s in order to explore the effect of L1 on the use of Norwegian PVs. In the present study, PVs were examined in free writing. The use of PVs in spoken language may be different, and it would require a new study. 


\section{Acknowledgements}

I would like to thank the anonymous reviewers, as well as the participants who took part in the study.

\section{Endnotes}

${ }^{1}$ Non-conventionalized expressions, e.g. bære ei veske 'to carry a bag', are of the type where words can be freely combined (Enström, 1996).

2 According to Faarlund et al. (1997, p. 412, 446) verbal particles are syntactically prepositions. Faarlund's view is incompatible with the fact that the particles do not take complements of their own.

3 I will primarily use the terms transparent and idiomatic here although literal/directional and figurative/non-compositional are more established in the research literature.

4 For example Celce-Murcia \& Larsen-Freeman (1999) and Dehé (2002) divide English PVs into three groups (literal, figurative /idiomatic and aspectual PVs).

${ }^{5}$ In Norwegian aktionsart stems not only from the verb or the verb phrase but is also conveyed by the entire sentence or clause. Definiteness may change the aktionsart, vi sang triste sanger 'we sang sad songs' (unbounded aktionsart) vs. vi sang nasjonalsangen 'we sang the national anthem' (bounded aktionsart; see Faarlund et al., 1997, p. 637-644, 703; Zielonka, 2004, p. 173). In the Finnish language, the process is often expressed by cases, e.g. ajaa autoa, 'to drive a car' (partitive case/atelic) vs. ajaa auto talliin, 'to drive a car into the garage (successfully)' (nominative case/telic) or derivational morphemes lukea, 'read' vs. lueskella, 'be reading' (VISK § 1498; 305318; see also Lehismets, 2014, p.105; Sjöholm, 1995, p. 100-101).

${ }^{6}$ Here, the preposition could also be analyzed as an object marker on a par with e.g. in in confide in somebody. It is supported by the fact that the P cannot occur behind the NP here (Rostila, 2018).

7 This information is based on earlier data of the language use (Lieri 2017, 2019). The subjects were asked how much they use Finnish/Norwegian in their daily life and for what purposes.

8 Leksikografisk bokmålskorpus has about 100 million words in bokmål from 1985 to 2013. The corpus contains non-fiction, fictional texts and newspaper texts.

${ }^{9}$ In both S-languages and V-languages, expressions lexicalizing motion events in non-typically appropriate ways can be found (Alejo Conzález, 2010), e.g. in Italian uscire vs. andare fuori 'to go out'.

\section{References}

Aa, L. I. (2015). The Grammar of Verb-Particle Constructions in Spoken Norwegian. (Doctoral dissertation). Norwegian University of Science and Technology, Trondheim, Norway. https:// brage.bibsys.no/xmlui/handle/11250/2360519

Alejo González, R. (2010). Making sense of phrasal verbs. A cognitive linguistic account of L2 learning. Applied cognitive linguistics in second language learning and teaching AILA review, 23 (1), 50-71.

Armstrong, K. (2004). Sexing up the Dossier: A Semantic Analysis of Phrasal Verbs for Language Teachers. Language Awareness 13(4), 213-224. 
Berntsen, H. (2009). Norske partikkelverb og oversettelse til spansk. En detaljert analyse av norske partikkelverb og en kontrastiv analyse mellom norsk og spansk som belyser hvordan spanske oversetter oppfatter disse [Norwegian particle verbs and translation into Spanish. A detailed analysis of Norwegian particle verbs and a contrastive analysis between Norwegian and Spanish that illustrate how Spanish translators perceive these]. (Master's thesis in linguistics). University of Oslo, Norway.

Blais, M. J., \& Gonnerman, L. M. (2013). Explicit and implicit semantic processing of verbal-particles constructions by French-English bilinguals. Bilingualism: Language and Cognition, 16 (4), 829-846.

Boers, F., \& Lindstroemberg, S. (2008). How Cognitive linguistics can foster effective vocabulary teaching. In F. Boers \& S. Lindstroemberg (Eds.), Cognitive Linguistic Approaches to Teaching vocabulary and Phraseology (pp. 1-61). Mouton de Gruyter: Berlin/New York.

Bokmålsordboka [The Bokmål Dictionary] (1994). Retrieved from https://ordbok.uib.no/ perl/ordbok.cgi?OPP $=$ reference $\% 20$ samples

Bybee, J. (2006). From Usage to Grammar: The Mind's Response to Repetition. Language $82(4), 711-733$.

Celce-Murcia, M., \& Larsen-Freeman, D. (1999). The grammar book: An ESL/EFL teacher's course. Boston, MA: Heinle and Heinle.

Chaudron, C. (2003). Data Collection in SLA Research. In C. Doughty, \& M. Long (Eds.), The Handbook of Second language acquisition (pp.726-828). Oxford, England: Blackwell.

Croft, W., \& Cruse, D. A. (2004). Cognitive Linguistics. Cambridge: Cambridge University Press.

Dehé, N. (2002). Particle Verbs in English: Syntax, Information Structure, and Intonation. Amsterdam: John Benjamins Publishing Company.

Dehé, N. (2015). Particle verbs in Germanic. In P. O. Müller, I. Ohnheiser, S. Olsen, \& F. Rainer (Eds.), Word formation. An international handbook of Europe (HSK series) (pp. 611-626). Berlin: De Gryter.

Det Norske Akademis ordbok [The Norwegian Academic Dictionary] (2017). Retrieved from https://www.naob.no/

Eeg, L. (2017). Sematisk analyse av norske verb og preposisjonar som frase og i prepsosisjonverb-samansetningar. Ein korpusstudie [Semantic analysis of Norwegian verbs and prepositions as phrase and in preposition verb combinations. A corpus study]. (Master's thesis). University of Oslo, Norway. https://www.duo.uio.no/bitstream/ handle/10852/57408/MA-LE-2017.pdf?sequence=1

Ekberg, L. (1999). Användningen av komplexa predikat hos invandrarbarn i Rosengård [The use of complex predicates in immigrant children in Rosengård]. In L.-G. Andersson et al. (Eds.), Svenskans beskrivning 23 (pp. 86-95). Lund: Lund University Press.

Ellis, N. C. (2002). Frequency effects in language processing and acquisition: A review with implications for theories of implicit and explicit language acquisition. Studies in Second Language Acquisition, 24, 143-188.

Enström, I. (1996). Klara verba. Andraspråksinlärares verbanvändning $i$ svenskan [Clearing up the verbs: second language learners' use of verbs in Swedish]. Nordistica Gothoburgensia 18. Göteborg: Acta Universitatis Gothoburgensis.

Enström, I. (2013). Ordförråd och ordinlärning - med särskilt fokus på avancerade inlärare [Vocabulary and word learning-with particular focus on advanced learners]. In K. Hyltenstam, \& I. Lindberg (Eds.): Svenska som andraspråk -i forskning, undervisning och samhälle [Swedish as a second language - in research, teaching and society] (pp.169-195). Lund: Studentlitteratur.

Faarlund, J., Lie, S., \& Vannebo, K. I. (1997). Norsk referansegrammatikk [A Norwegian Reference Grammar]. Oslo: Universitetsforlaget.

Goldberg, A. E. (2006). Constructions at work: The nature of generalization in language. Oxford: Oxford University Press.

Golden, A. (2005). A gripe poenget. Forståelse av metaforiske uttrykk fra lærebøker $i$ samfunnskunskap hos minoritetselever i ungdomsskolen [To seize the point. Understanding metaphorical expressions from textbooks in social studies at minority students in secondary school]. (Doctoral disseratation). Oslo: UniPub. 
Golden, A. (2017). Ord i Nord. Forskning på ordforråd, ordbruk og ordlæring i et andrespråksperspektiv i Norden [Words in the North. Research on vocabulary, vocabulary use and vocabulary learning in a second language perspective in the Nordic region]. In E. Sköldberg, M. Andréasson, H. Adamsson Eryd, F. Lindahl, S. Lindström, J. Prentice \& M. Sandberg (Eds.), Svenskans beskrivning 35. Förhandlingar vid trettiofemte sammankomsten Göteborg 11-13 maj 2016 (pp.1-17). Göteborgsstudier i nordisk språkvetenskap 29. Göteborgs universitet.

Golden, A., MacDonald, K., \& Ryan, E. (2014). Norsk som fremmedspråk [Norwegian as a foreign language]. (4th ed.). Oslo: Universitetsforlaget.

Gujord, Helland A-K. (2013). Akjsonsart - ein diskusjon av vanskar knytt til klassifisering av verbfrasar i aksjosnart i innlærerspråk [Aktionart -a discussion of difficulties associated with the classification of verb phrases in aktionart in a learner language]. Nordand - Nordisk tidskrift for andrespråksforskning, 8(2), 35-60.

Gustafsson, H., Verspoor, M., \& Lowie, W. (2012). Conventionalized ways of saying things (CWOSTs) and L2 development. Dutch Journal of Applied Linguistics, 1(1), 125-142.

Haugen, T. A. (2009). To typar verbalpartiklar i norsk [Two types of verbal particles in Norwegian]. Norsk Lingvistisk Tidskrift, 27, 239-266.

Holum, L-M. (2010). Å utrykke bevegelse på et andrespråk [To express motion in a second language]. NOA - norsk som andrespråk 26 (2), 5-35.

Hovland, O.S. (1997). «Verb+partikkel». Andrespråkselevar sin bruk av ein særeigen verbkonstruksjon $i$ norsk - ei førebuande undersøking og det teoretiske grunnlaget [«Verb+Particle». Second language users' use of particular verbal construction in Norwegian - a preemptive study and theoretical framework]. (Master's thesis). University of Bergen, Norway.

Hulstijn, J. H., \& Marchena, E. (1989). Avoidance: Grammatical or semantic causes? Studies in Second Language Learning Acquisition, 11(3), 241-255.

Kecskes, I. (2015). Is the Idiom Principle Blocked in Bilingual Language Production? In R. R. Heredia, \& A. B. Cieślicka (Eds.), Bilingual Figurative Language Processing (pp. 28-52). Cambridge: Cambridge University Press.

Kharitonova, A. (2013). Lexical transfer and avoidance in the acquisition of English phrasal verbs. Evidence from Russian and Norwegian learners of English. (Master's thesis). University of Oslo, Norway.

Kolehmainen, L. (2006). Saksan ja suomen verbien morfologiaa, fraseologiaa, semantiikkaa ja valenssinmuutoksia [Morphology, phraseology, semantics and valence changes of German and Finnish verbs]. Väitöksen alkajaisesitelmä Helsingin yliopistossa 3.12.2005. Virittäjä, 110 (2).

Kolehmainen, L., Meriläinen L., \& Riionheimo, H. (2014). Interlingual reduction: Evidence from Language Contacts, Translation and Second Language Acquisition. In H. Paulasto, L. Meriläinen, H. Riionheimo, \& M. Kok (Eds.), Language Contacts at the Crossroads of Disciplines (pp. 3-32). Newcastle-upon-Tyne: Cambridge Scholars Publishing.

Langacker, R.W. (1987). Foundations of Cognitive Grammar. Volume I, Theoretical Prerequisites. Stanford: Stanford University Press.

Langacker, R. W. (2000). A dynamic usage-based model. In M. Barlow, \& S. Kemmer (Eds.), Usage-based models of language (pp. 1-63). Stanford, CA: CSLI Publications.

Larsen, D. (2014). Particles and particle-verb constructions in English and other Germanic languages. (Doctoral dissertation). Delaware University, USA. http://dspace.udel.edu/bitstream/ handle/19716/13395/2014_Larsen_Darrell_PhD.pdf?sequence $=1 \&$ isAllowed=y

Larsen-Freeman, D. (1997). Chaos/Complexity Science and Second Language Acquisition. Applied Linguistics, 18(2), 141-165.

Larsson, I., \& Lundquist, B. (2014). Objektsplacering vid partikelverb i norska dialekter och äldre svenska [Object placement for particle verbs in Norwegian dialects and older Swedish]. In J. Bondi Johannessen, \& K. Hagen (Eds.), Språket $i$ Norge og nabolanda - Ny forskning om talespråk [The language in Norway and neighboring countries - New research on spoken language] (pp. 93-131). Oslo: Novus forlag. 
Laufer, B., \& Eliasson, S. (1993). What causes avoidance in second language learning: L1-L2 difference, L1-L2 similarity, or L2 complexity? Studies in Second Language Learning Acquisition, 15, 35-48.

Lehismets, K. (2014). Bipositions and motion events: How verb semantics motivates prepositional vs. postpositional uses of Finnish path adpositions. Folia Linguistica, 48(1), 85-118.

Leksikografisk bokmålskorpus [the Corpus for Bokmål Lexicography] (2018). Retrieved from https://www.hf.uio.no/iln/tjenester/kunnskap /sprak/korpus/skriftsprakskorpus/lbk/

Liao, Y., \& Fukuya,Y. L. (2004). Avoidance of phrasal verbs: The case of Chinese learners of English. Language Learning, 54, 193-226.

Lieri, K. (2017). Språkanvändning och språkval bland finsk-norska ungdomar i Osloområdet. Puhe ja kieli 37 (2), 55-76.

Lieri, K.(2019). Puheessa esiintyvistä riittävyyden verbeistä norjansuomalaisilla nuorilla (Verbs of sufficiency in spontaneous speech among Finnish-Norwegian adolescents). Virittäjä 123(1), 79-109.

Liu, D. (2011). The most frequently used phrasal verbs in American and British English. A Multicorpus examination. Tesol Quarterly, 45(4), 661-688.

Liu, D., \& Myers, D. (2018). The most common phrasal verbs with their key meanings for spoken and academic written English: A corpus analysis. Language Teaching Research, 1-22.

Mondor, M. (2008). Figuring it out. A corpus-based comparison of the verb-particle construction in argumentative writing by Swedish advanced learners and native speakers of English. (Doctoral thesis). University of Gothenburg, Sweden.

Paulmann, S., Ghareeb-Ali, Z., \& Felser, C. (2015). Neurophysiological Markers of Phrasal Verb Processing. In R. R. Heredia, \& A. B. Cieślicka (Eds.), Bilingual Figurative Language Processing (pp. 245-267). Cambridge: Cambridge University Press.

Pawley, A., \& Syder, F. (1983). Two puzzles for linguistic theory: nativelike selection and nativelike fluency. In J. C. Richards, \& R. W. Schmidt (Eds.), Language and Communication (pp.191-226). London: Longman.

Pellicer-Sánchez, A., \& Boers, F. (2019). Teaching and Learning of Formulaic Language. In A. Siyanova-Chanturia, \& A. Pellicer-Sánchez (Eds.), Understanding Formulaic Language. A Second Language Acquisition Perspective (pp.153-173). New York: Routledge.

Rostila, J. P. (2018). Goldberg's Rely On construction: Overreliance on generalization? In M. Kaunisto, M. Höglund, \& P. Rickman (Eds.), Changing Structures: Studies in constructions and complementation (pp. 55-68). (Studies in Language Companion Series; No. 195). Amsterdam: John Benjamins.

Schmitt, N., \& Redwood, S. (2011). Learner knowledge of phrasal verbs: a corpus-informed study. In F. Meunier, S. De Cock, G. Gilquin, \& M. Paquot (Eds.), A Taste for Corpora: In honour of Sylviane Granger (pp. 173-208). Amsterdam: John Benjamin Publishing Company.

Siyanova, A., \& Schmitt, N. (2007). Native and nonnative use of multi-word vs. oneword verbs. International Review of Applied Linguistics, 45, 119-139.

Siyanova-Chanturia, A., \& van Lancker Sidtis, D. (2019). What Online Processing Tells us About Formulaic Language. In A. Siyanova-Chanturia, \& A. Pellicer-Sánchez (Eds.), Understanding Formulaic Language. A Second Language Acquistion Perspective (pp. 38-61). New York: Routledge.

Sjöholm, K. (1995). The influence of Crosslinguistic, Semantic and Input Factors on the Acquisition of English Phrasal Verbs. A Comparison between Finnish and Swedish Learners at an intermediate and advanced level. (Doctoral dissertation). Turku: Åbo Akademi University Press.

Strzelecka, E. (2003). Svenska partikelverb med in, ut, upp och ner. En semantisk studie ur kognitivt perspektiv [Swedish particle verbs with in, out, up, and down. A semantic study from a cognitive perspective]. (Doctoral disseration). Uppsala University, Sweden. https:// www.diva-portal.org/smash/get/diva2:31074/FULLTEXT01.pdf

Sundman. M. (2010). Prepositioner som partiklar - ett grammatiskt continuum i svenskan [Prepositions as particles - a grammatical continuum in the Swedish]? In G. Byrman, A. Gustafsson \& H. Rahm (Eds.), Svensson och svenskan. Med sinnen känsliga för språk. Festskrift till Jan Svensson den 24 januari 2010 (pp. 309-318). Lund: Lunds universitets publikationer.

Talmy, L. 2000: Toward a cognitive semantics: Typology and process in concept structuring. Volume II. Cambridge, Massachusetts: MIT Press. 
Taylor, J. R. (2002). Cognitive Grammar. Oxford: Oxford University Press.

Thornbury, S. (2002). How to teach vocabulary. Essex: Pearson Education Limited.

Tomasello, M. (2003). Constructing a language: a usage-based theory of language acquisition. Cambridge, Massachusetts: Harvard University Press.

Treffers-Daller, J. (2018). The Measurement of Bilingual Abilities. In A. De Houwer, \& L. Ortega (Eds.). The Cambridge Handbook of Bilingualism (pp. 289-306). Cambridge: Cambridge University Press.

Vendler, T. (1957).Verbs and Times. The Philosophical Review. 66(2), 143-160.

Viberg, Å. (2004). Lexikal utveckling i ett andraspråk [Lexical development i an L2]. In K. Hyltenstam \& I. Lindberg (Eds.), Svenska som andraspråk -i forskning, undervsining och samhälle [Swedish as a second language - in research, teaching and society] (pp. 197-220). Lund: Studentlitteratur.

VISK = Hakulinen, A., Vilkuna, M., Korhonen, R., Koivisto, V., Heinonen, T. R., \& Alho, I. (2004). Iso suomen kielioppi [Comprehensive Grammar of Finnish online]. Helsinki: Suomalaisen Kirjallisuuden Seura. http://scripta.kotus.fi/visk URN:ISBN:978-9525446-35-7 (12.1.2019)

Walková, M. (2015). English Aspectual particles are of two types. Linguistics, 16 (2-3), 149-168. https://hrcak.srce.hr/jezikoslovlje

White, B. J. (2012). A Conceptual Approach to the Instruction of Phrasal Verbs. Modern Language Journal, 96(3), 419-438.

Wray, A. (2002). Formulaic Language and the Lexicon. Cambridge: Cambridge University Press.

Yildiz, M. (2016). A Cross-Linguistic Inquiry into the Potential Reasons for the Avoidance of English Phrasal Verbs: The Case of Turkish and Norwegian EFL Learners. The Linguistics Journal, 10 (1), 124-140.

Ylikiiskilä, A. (2001). Tvåspråkiga skolbarns verbanvändning $i$ svenska [Bilingual school children's use of verbs in Swedish]. (Doctoral dissertation). Acta Universitatis Stockholmiensis. Studies in Scandinavian Philology. New Series 24. Stockholm: Almqvist \& Wiksell International.

Zielonka, B. (2004). Aktionsart or aspect? Folia Scandinavica 8, 169-180.

Zivanovic, M. (2016). Et oppgjør med OPP: En leksikalsk-semantisk beskrivelse av verbalpartikkelen OPP [A settlement with OPP. A lexical-semantic description of the verbal particle OPP]. (Master's thesis). University of Oslo, Norway. 


\section{Appendices}

\section{Appendix 1.}

Table 1. Particle verbs in the emails.

\begin{tabular}{|c|c|c|c|}
\hline $\begin{array}{c}\text { L2 speakers of } \\
\text { Norwegian (L1 } \\
\text { Finnish; FN group) }\end{array}$ & & $\begin{array}{c}\text { L1 speakers } \\
\text { (native speakers of } \\
\text { Norwegian; NO group) }\end{array}$ & \\
\hline Transparent PVs & Idiomatic PVs & Transparent PVs & Idiomatic PVs \\
\hline $\begin{array}{l}\text { Komme inn } 5 \\
\text { Komme hjem } 4 \\
\text { Gå ut } 4 \\
\text { Dra opp } 2 \\
\text { Stå opp } 1 \\
\text { Reise rundt } 1 \\
\text { Ta opp } 1 \\
\text { Komme frem } 1 \\
\text { Pakke ut } 1\end{array}$ & $\begin{array}{l}\text { Vokse opp } 7 \\
\text { Slappe av } 2 \\
\text { Ende opp } 1 \\
\text { Gå opp } 1 \\
\text { Skille seg ut } 1 \\
\text { Se opp til } 1 \\
\text { Fryse ned } 1 \\
\text { Få til } 1 \\
\text { Slå til } 1 \\
\text { Dra ut } 1 \\
\text { Høres ut } 1 \\
\text { Gå an } 1 \\
\text { Stå på } 1 \\
\text { Gi opp } 1 \\
\text { Finne ut } 1\end{array}$ & $\begin{array}{l}\text { Komme hjem } 6 \\
\text { Stå opp } 4 \\
\text { Komme inn } 3 \\
\text { Gå inn } 2 \\
\text { Kjøre rundt } 2 \\
\text { Reise bort } 2 \\
\text { Komme ut } 1 \\
\text { Kjøre ut } 1 \\
\text { Holde inne } 1 \\
\text { Levere inn } 1 \\
\text { Varme opp } 1 \\
\text { Ta inn } 1 \\
\text { Sette i gang } 1 \\
\text { Slå sammen } 1 \\
\text { Gå ut } 1 \\
\text { Sette seg ned } 1\end{array}$ & $\begin{array}{l}\text { Kjøre opp } 3 \\
\text { Finne ut } 2 \\
\text { Stå for } 1 \\
\text { Se ut } 1 \\
\text { Gi opp } 1 \\
\text { Gå over } 1 \\
\text { Kaste opp } 1 \\
\text { Komme an på } 1 \\
\text { Fylle ut } 1 \\
\text { Ta på seg } 1 \\
\text { Ta av seg } 1 \\
\text { Kle på seg } 1 \\
\text { Slå på } 1 \\
\text { Slå ut } 1\end{array}$ \\
\hline
\end{tabular}

Received September 5, 2019 